\title{
Article \\ Copper and Zinc Recovery from Sulfide Concentrate by Novel Artificial Microbial Community
}

\author{
Xinglan Cui ${ }^{1,2,3,4,+}$, Xuetao Yuan ${ }^{1,2,+}$, Hongxia Li ${ }^{1,2,3,4}$, Xiaokui Che ${ }^{1,2}$, Juan Zhong ${ }^{1,2,3,4}$, Lei Wang ${ }^{1,2,3,4}$, \\ Ying Liu ${ }^{1,2, *}$, Xuewu Hu ${ }^{1,2,5}$, Qidong Zhang ${ }^{1,2}$, Rongzhen Jin ${ }^{1,2,5}$ and Qi Zheng ${ }^{1,2}$ \\ 1 The National Engineering Research Center for Environment-Friendly Metallurgy in Producing Premium \\ Non-Ferrous Metals, GRINM Resources and Environmental Technology Corporation Limited, \\ Beijing 101407, China; cuixinglan@grinm.com (X.C.); yuanxt@grinm.com (X.Y.); lihongxia@grinm.com (H.L.); \\ xkche@grinm.com (X.C.); zhongjuan@grinm.com (J.Z.); wanglei@grinm.com (L.W.); \\ b20170142@xs.ustb.edu.cn (X.H.); zhangqidong@grinm.com (Q.Z.); kimyeongjin@hotmail.com (R.J.); \\ Mr1311@grinm.com (Q.Z.) \\ 2 GRINM Group Corporation Limited, Beijing 100088, China \\ 3 GRIMAT Engineering Institute Corporation Limited, Beijing 100088, China \\ 4 State Key Laboratory of Vanadium and Titanium Resources Comprehensive Utilization, \\ Panzhihua 617000, China \\ 5 Beijing Key Laboratory of Resource-Oriented Treatment of Industrial Pollutants, University of Science and \\ Technology Beijing, Beijing 100083, China \\ * Correspondence: rddly@grinm.com \\ + These authors contributed equally to this work.
}

Citation: Cui, X.; Yuan, X.; Li, H.; Che, X.; Zhong, J.; Wang, L.; Liu, Y.; $\mathrm{Hu}$, X.; Zhang, Q.; Jin, R.; et al. Copper and Zinc Recovery from Sulfide Concentrate by Novel Artificial Microbial Community. Metals 2022, 12, 45. https:/ / doi.org/10.3390/met12010045

Academic Editor: Antoni Roca

Received: 7 October 2021

Accepted: 22 December 2021

Published: 25 December 2021

Publisher's Note: MDPI stays neutral with regard to jurisdictional claims in published maps and institutional affiliations.

Copyright: (c) 2021 by the authors. Licensee MDPI, Basel, Switzerland. This article is an open access article distributed under the terms and conditions of the Creative Commons Attribution (CC BY) license (https:// creativecommons.org/licenses/by/ $4.0 /)$.

\begin{abstract}
Exploring efficient methods to enhance leaching efficiency is critical for bioleaching technology to deal with sulfide concentrate. In our study, a novel artificial microbial community was established to augment the bioleaching efficiency and recovery of copper $(\mathrm{Cu})$ and zinc $(\mathrm{Zn})$. The optimum parameters in bioleaching experiments were explored according to compare a series of conditions from gradient experiments: the $\mathrm{pH}$ value was 1.2 , temperature was $45^{\circ} \mathrm{C}$, and rotation speed was $160 \mathrm{r} / \mathrm{min}$, which were different with pure microorganism growth conditions. Under optimal conditions, the result of recovery for $\mathrm{Cu}$ and $\mathrm{Zn}$ indicated that the average leaching rate reached to $80 \%$ and $100 \%$ respectively, which almost increased 1.8 times and 1.2 times more than control (aseptic condition) group. Therefore, this method of $\mathrm{Cu}$ and $\mathrm{Zn}$ recovery using a new-type artificial microbial community is expected to be an environmentally-friendly and efficient bioleaching technology solution, which has the potential of large-field engineering application in the future.
\end{abstract}

Keywords: copper; zinc; recovery; sulfide concentrate; artificial microbial community

\section{Introduction}

Mineral resources are the economic and material basis of human society. In recent years, with the proposal of green mine development concept, efficient exploitation of mineral resources and reduction of ecological environmental impact have been important principles for future exploitation and utilization of mineral resources [1]. However, most mines in China have backward mining technology, enormous destruction and waste, too low recycling proportion, and low management efficiency [2]. As is known to us, with continuous decline in copper rich ore reserves, reprocessing of low-grade copper-bearing sulfide ores, accounting for $>70 \%$ of the global copper reserves, has become inevitable [3-5]. Unfortunately, metal extraction from these low-grade ores using traditional smelting techniques is uneconomical. Therefore, most low-grade ores have been discarded [6-8].

In the last two decades, extensive efforts have been made to apply microbes to sulfides leaching due to demand of ores and low costs $[9,10]$. Biological processes are effective methods and the interaction between microorganisms and minerals has been a hot topic to reveal the transformation of key elements affecting bioleaching efficiency [11,12]. Moreover, bioleaching attracts increasingly more attention for its simplified operation, low cost, and 
environmentally friendly benefits $[13,14]$. In the bioleaching process, structural metals in solid materials are transformed into soluble and extractable ones by microorganisms through biological oxidation or complexation processes for easy recovery [15]. Bioleaching has been actively studied for years to deal with metal-contaminated sludge and environments, such as sediment and soil, and the removal efficiency of most heavy metals is usually higher than 85\% [16-19]. Bioleaching facilitates metal mobilization from solid sources via different biologically catalyzed reactions mediated by different microbial leaching agents such as (in)organic acids. A wide range of microorganisms such as chemolithoautotrophic bacteria, archaea, and fungi have been applied for bioleaching of metals from different solid materials [20-23].

In the bioleaching technology, microorganisms, such as Acidithiobacillus ferrooxidans, Acidithiobacillus thiooxidans, Acidithiobacillus caldus, Leptospirillum ferrooxidans, and Ferroplasma spp., are often employed to enhance the dissolution process of copper sulfide ores [24]. The detailed bioleaching efficiency for metals of several microbes is listed in Table 1. Obviously, the community which consists of Acidithiobacillus thiooxidans, Acidithiobacillus ferrooxidans, and Leptospirillum ferriphilum had lower leaching efficiency for $\mathrm{Cu}$ and $\mathrm{Zn}$ and $\mathrm{pH}$ value was 2.0-2.2 in 25 days, which only reached $69-83 \%$ and $4.1-14 \%$ respectively [25]. Further research used two bacteria including Acidithiobacillus thiooxidans and Acidithiobacillus ferrooxidans. The leaching efficiency of $\mathrm{Cu}$ and $\mathrm{Zn}$ reached $38 \%$ and $\mathrm{Zn}$ 67\% [26]. Furthermore, another previous study showed that Bacillus megaterium QM B1551 can extract valuable metals such as $\mathrm{Co}, \mathrm{Ni}$, and $\mathrm{Cu}$ from a complex sulfide flotation concentrate, but the $\mathrm{Cu}$ only leached 39.8\% [27]. Meanwhile, the bioleaching potential of indigenous Aspergillus fumigatus to remove metals was evidenced and the leaching efficiency reached $100 \%, 62 \%, 58 \%, 56 \%$, and $54 \%$ for $\mathrm{Mn}$, As, Fe, $\mathrm{Pb}$, and $\mathrm{Zn}$, respectively [28]. Moreover, Aspergillus niger was used to treated waste LCD panels, and the indium bioleaching efficiency could be improved from $12.3 \%$ to $100 \%$ by fermentation method optimization [29], but the method process speed time was more than $15 \mathrm{~h}$. Additionally, the microbial leaching of heavy metal from municipal sludge was studied in a continuously stirred tank reactor, and about $62 \%$ of $\mathrm{Cu}$ and about $77 \%$ of $\mathrm{Zn}$ were dissolved [30]. Above all, the majority of bioleaching experiments employed single wild microorganisms, which means that the leaching efficiency was relatively limited. Some researchers improved the experimental system with microbes used as the target and adopted the mixed community system, which greatly improved the leaching efficiency [26,29,31,32]. However, to our knowledge, there is little research focus on exploring the simultaneous improvement of $\mathrm{Cu}$ and $\mathrm{Zn}$ leaching efficiency in polymetallic ore remains.

Table 1. The advance in leaching metals technological scheme.

\begin{tabular}{|c|c|c|}
\hline Microbe or Method & Result (Leaching Efficiency) & Reference \\
\hline Aspergillus fumigatus & As $(62 \%), \mathrm{Fe}(58 \%), \mathrm{Mn}(100 \%), \mathrm{Zn}(54 \%)$ & Bahi Jalili Seh-Bardan et al., 2012 [28] \\
\hline Acidithiobacillus thiooxidans; & & \\
\hline $\begin{array}{l}\text { Acidithiobacillus ferrooxidans; Leptospirillum } \\
\text { ferriphilum }\end{array}$ & $\mathrm{Cu}(69 \sim 83 \%) ; \mathrm{Zn}(4.1 \sim 14 \%)$ & Olli H. Tuovinen et al., 2015 [25] \\
\hline Acidithiobacillus thiooxidans; & $C_{1}(38 \%) \cdot 7 n(67 \%)$ & Van Khanh Nguyen and Jong-Un Lee., \\
\hline Acidithiobacillus ferrooxidans & $\mathrm{Cu}(38 \%) ; \operatorname{Zn}(6 / \%)$ & 2015 [26] \\
\hline Bacillus megaterium QM B1551 & $\mathrm{Co}(60.7 \%) ; \mathrm{Ni}(76.3 \%) ; \mathrm{Cu}(39.8 \%)$ & Xinlan Cui et al., 2016 [27] \\
\hline $\begin{array}{l}\text { Acidithiobacillus sp., Leptopirillum sp., } \\
\text { Ferroplasma sp. }\end{array}$ & $\begin{array}{l}\text { Pyrite }(69.29 \%) \text {; Chalcocite }(65.02 \%) \text {; } \\
\text { Covellite }(84.97 \%)\end{array}$ & Shang He et al., 2021 [24] \\
\hline Aspergillus niger & Indium $(100 \%)$ & Jiaying Cui et al., 2021 [29] \\
\hline Chemical leaching & $\mathrm{Zn}(85 \%) ; \mathrm{Cu}$ and $\mathrm{Fe}(10 \%)$ & Jia Li et al., 2021 [33] \\
\hline Acidithiobacillus ferrooxidans & $\mathrm{Cu}(54 \%) ; \mathrm{Ni}(75 \%), \mathrm{Fe}(55 \%)$ & Mahdokht Arshadi et al., 2021 [34] \\
\hline
\end{tabular}

In our study, we aim to adopt a new microbial culture method to cultivate a newtype artificial microbial community to leach $\mathrm{Cu}$ and $\mathrm{Zn}$ from sulfide concentrate, and explore the influence of different conditions (temperature, $\mathrm{pH}$ value, and rotation speed) 
on metal recovery, to further research and development of environmentally friendly and efficient bioleaching technology. An artificial microbial community consisting of Sulfobacillus thermotolerans 6Y-1, Leptosirillum ferriphilum MJ-CL, and Acidithiobacillus caldus OY (the concentration ratio is 1:1:1) was established for targeted and efficient recovering of copper and zinc from sulfide concentrate. Furthermore, different $\mathrm{pH}$ value, temperature, and rotation speed gradient were determined for the optimal conditions by the artificial microbial community. Then, the preferred conditions were chosen for bioleaching efficiency of $\mathrm{Cu}$ and $\mathrm{Zn}$, using this novel artificial microbial community, which provided a new-type and high-efficiency method for recovering of copper and zinc from low-grade ores.

\section{Materials and Methods}

\subsection{Sample Source and Mineral Component Analysis}

The sulfide concentrate used in our study was from Qinghai Derni flotation sulfide concentrate. The mineral component was characterized by X-ray diffraction (XRD) on a Philips Diffractometer (model: X'Pert-Pro MPD; Philips, Eindhoven, The Netherland) using $\mathrm{CuK} \alpha$ radiation $(\lambda=0.15418 \mathrm{~nm}, 45 \mathrm{kV}, 200 \mathrm{~mA})$. Diffraction patterns covering a $2 \theta$ range of $10^{\circ}-90^{\circ}$ were measured at a step size of $0.02^{\circ}$. The scanning speed was $8^{\circ} / \mathrm{min}$ and all the tests were carried out at room temperature.

The chemical and elemental composition of the sulfide concentrate sample was characterized by X-ray fluorescence spectrometer (XRF) (Model: ARL Advant XP, Thermo Electron Corporation, Berne, Switzerland). All measurements have been done with the excitation power of $4.2 \mathrm{~kW}, 50 \mathrm{kV}$ excitation voltage and $55 \mathrm{~mA}$ excitation current.

The chemical analyses of the screened samples and mineralogical data were obtained from mineral liberation analyses (MLA, $650 \mathrm{~F}$ ) equipped with a Bruker EDX (energy dispersive X-ray) system and MLA suite 3.1 for data acquisition.

\subsection{Culture for the Artificial Microbial Community}

Bacteria of the genus Sulfobacillus are successfully used in biotechnologies of treatment of sulfide ore materials [32]. Cultures deposited in China Center for Type Culture Collection (CCTCC) were used in the study. The artificial microbial community was constituted by Sulfobacillus thermotolerans 6Y-1 (CCTCC No. M2010279), Leptosirillum ferriphilum MJ-CL (CCTCC No. M2011019), and Acidithiobacillus caldus OY (CCTCC No. M2010356) (with a concentration ratio for 1:1:1). The artificial microbial community was cultured with a medium containing: $44.7 \mathrm{~g} / \mathrm{L}$ of $\mathrm{FeSO}_{4} \cdot 7 \mathrm{H}_{2} \mathrm{O}, 3 \mathrm{~g} / \mathrm{L}$ of $\left(\mathrm{NH}_{4}\right)_{2} \mathrm{SO}_{4}, 0.1 \mathrm{~g} / \mathrm{L}$ of $\mathrm{KCl}, 0.5 \mathrm{~g} / \mathrm{L}$ of $\mathrm{K}_{2} \mathrm{HPO}_{4}, 0.5 \mathrm{~g} / \mathrm{L}$ of $\mathrm{MgSO}_{4} \cdot 7 \mathrm{H}_{2} \mathrm{O}, 0.01 \mathrm{~g} / \mathrm{L}$ of $\mathrm{Ca}\left(\mathrm{NO}_{3}\right)_{2}$. The value of the medium was adjusted by using $1 \mathrm{~mol} / \mathrm{L}$ sulfuric acid. The artificial microbial community was aerobically inoculated in $100 \mathrm{~mL}$ medium at $45^{\circ} \mathrm{C}$ condition with shaking speed of $160 \mathrm{r} / \mathrm{min}$ for 3 days. Then it was inoculated with $5 \mathrm{~mL}$ microbial suspension into $100 \mathrm{~mL}$ medium and reactivated two times until the optical density at $600 \mathrm{~nm}\left(\mathrm{OD}_{600}\right)$ reached about 1.5. The number of bacteria in bacterial liquid was directly counted by blood counting plate under light microscope (Nikon ECL IPSE 50I). The $\mathrm{pH}$ value of the solution was measured by using a pH meter (Orion 868A, ThermoFisher, Waltham, MA, USA).

\subsection{Chemical Analysis Procedure of Leached Elements}

As for leaching process experiment, $20 \mathrm{~g}$ sulfide concentrate sample, $90 \mathrm{~mL}$ medium, and $10 \mathrm{~mL}$ logarithmic phase microbial community solution were placed into $250 \mathrm{~mL}$ conical flask. The initial $\mathrm{pH}$ and different temperature conditions were controlled. During leaching process, $5 \mathrm{~mL}$ samples of suspension were aseptically removed at $24 \mathrm{~h}$ intervals. The distilled water was added to replenish the evaporated solution before sampling. After the leaching finished, the residual ore concentrate was separated into solids. The supernatant immediately by centrifugation (Eppendorf Centrifuge 5804R, Hamburg, Germany) with $11,000 \mathrm{r} / \mathrm{min}$ for $10 \mathrm{~min}$ to obtain the supernatant and sediment. The quantitative analysis of the main elements was carried out by ICP-OES (Inductively coupled plasma emission Spectrometer, Agilent 725-ES, Santa Clara, CA, USA). 


\section{Results and Discussion}

\subsection{Mineral Composition for Sulfide Concentrate}

With the aim of understanding the chemical constituents of sulfide concentrate, XRF was employed in the study. As shown in Table 2, the sulfide concentrate contained large amounts of $\mathrm{SO}_{3}(47.6 \%), \mathrm{Fe}_{2} \mathrm{O}_{3}(37.6 \%), \mathrm{SiO}_{2}$ (5.94\%), $\mathrm{MgO}(4.24 \%)$, and $\mathrm{CaO}(2.27 \%)$. In addition, there were several limited content chemical compounds, which including $\mathrm{ZnO}(0.730 \%), \mathrm{CuO}(0.540 \%), \mathrm{Al}_{2} \mathrm{O}_{3}(0.380 \%)$, and other oxides content was less than $0.100 \%$. Therefore, there were minute amount of oxides content of $\mathrm{Cu}$ and $\mathrm{Zn}$ in the sulfide concentrate.

Table 2. XRF Results for sulfide concentrate (wt $\%)$.

\begin{tabular}{|c|c|c|c|c|c|c|c|}
\hline Oxides & $\mathrm{Fe}_{2} \mathrm{O}_{3}$ & $\mathrm{SiO}_{2}$ & $\mathrm{MgO}$ & $\mathrm{CaO}$ & $\mathrm{Na}_{2} \mathrm{O}$ & $\mathrm{ZnO}$ & $\mathrm{CuO}$ \\
\hline Content & 37.6 & 5.94 & 4.24 & 2.27 & 0.540 & 0.730 & 0.540 \\
\hline Oxides & $\mathrm{Cr}_{2} \mathrm{O}_{3}$ & $\mathrm{TiO}_{2}$ & $\mathrm{MnO}$ & $\mathrm{K}_{2} \mathrm{O}$ & $\mathrm{NiO}$ & $\mathrm{Al}_{2} \mathrm{O}_{3}$ & $\mathrm{SO}_{3}$ \\
\hline Content & 0.0100 & 0.0100 & 0.0500 & 0.0100 & 0.0400 & 0.380 & 47.6 \\
\hline
\end{tabular}

Furthermore, chemical elements in the sulfide concentrate were determined by ICPOES. As shown in Table 3, the main elements in the sulfide concentrate were Fe $(48.5 \%), \mathrm{S}$ (32.3\%), Ca (1.41\%), Mg (1.32\%), Zn (0.890\%), Cu (0.600\%), and other lower content (less than $0.1 \%$ ) elements, such as $\mathrm{Al}, \mathrm{Mn}, \mathrm{Ni}, \mathrm{Na}, \mathrm{Ti}, \mathrm{Cr}, \mathrm{Pb}$, and $\mathrm{K}$.

Table 3. Main chemical constituents of sulfide concentrate (wt $\%)$.

\begin{tabular}{ccccccccc}
\hline Elements & $\mathbf{F e}$ & $\mathbf{S}$ & $\mathbf{S i}$ & $\mathbf{C a}$ & $\mathbf{M g}$ & $\mathbf{Z n}$ & $\mathbf{C u}$ & $\mathbf{A l}$ \\
\hline Content & 48.5 & 32.3 & 2.61 & 1.41 & 1.32 & 0.890 & 0.600 & 0.0600 \\
\hline Elements & $\mathbf{M n}$ & $\mathbf{N i}$ & $\mathbf{T i}$ & $\mathbf{C r}$ & $\mathbf{P b}$ & $\mathbf{K}$ & $\mathbf{N a}$ & \\
\hline Content & 0.0400 & 0.0300 & 0.0100 & 0.0100 & 0.0100 & 0.0100 & 0.0100 & \\
\hline
\end{tabular}

The powder X-ray diffraction (XRD) patterns for sulfide concentrate are shown in Figure 1. As can be seen, the main minerals of the sample are pyrite, pyrrhotite, chalcopyrite, sphalerite, and magnetite, similar to previous research [33]. In detail, the diffraction peaks were observed at $28.5^{\circ}, 33.0^{\circ}, 37.0^{\circ}, 40.7^{\circ}, 47.4^{\circ}, 56.3^{\circ}, 61.7^{\circ}, 64.3^{\circ}, 83.6^{\circ}$, and $88.3^{\circ}$ corresponding to the lattice planes of pyrite (111), (200), (210), (211), (220), (311), (023), (321), (332), and (422), respectively (PCPDF: 99-0087). Meanwhile, diffraction peaks appeared at $29.9^{\circ}, 33.8^{\circ}, 43.8^{\circ}, 53.1^{\circ}, 62.2^{\circ}$, and $71.2^{\circ}$ corresponding to the lattice planes of pyrrhotite (200), (205), (2010), (220), (400), and (1120), respectively (PCPDF: 29-0724). In addition, 29.4 $48.6^{\circ}$, and $81.6^{\circ}$ were assigned to three characteristic diffraction planes of chalcopyrite (112), (220), and (404) (PCPDF: 26-1116), and 47.5 $, 59.1^{\circ}, 76.8^{\circ}$ corresponding to planes of sphalerite (220), (222), and (331) (PCPDF: 05-0566). The XRD data revealed that pyrite and pyrrhotite have perfect crystallinity, but chalcopyrite and sphalerite are imperfect according to the sharpness differentiation of the peak shape. 




Figure 1. Powder XRD pattern for sulfide concentrate.

\subsection{MLA and Liberation Classes for Sulfide Concentrate}

Mineral Liberation Analysis (MLA) is the effective modern method to analyze mineral properties, especially the liberation of minerals which is very important to the separation of different minerals. The chemical analyses and main mineral constituent data obtained from MLA are presented in Table 4 and the minerals in sulfide concentrate could be divided into five categories as sulfide, oxide, carbonate minerals, sulfate minerals, and silicate minerals. Analyzing their particle size distribution in Figure 2a, the sulfide minerals including pyrite, pyrrhotite, chalcopyrite, sphalerite, and galena as a group and their particle size distribution is mainly between $10 \mu \mathrm{m}$ and $100 \mu \mathrm{m}$ (13-93\%). The particle size distribution of oxide minerals such as magnetite, hematite, chromite, and ilmenite with the percent of $26.5 \%$ lower than $10 \mu \mathrm{m}$ and all of them were lower than $125 \mu \mathrm{m}$. Moreover, the size distribution property of carbonate minerals (dolomite and calcite) and silicate minerals (enstatite, quartz, biotite, hornblende, and pyroxene) was similar to the oxide minerals. As far as sulfate minerals (anhydrite and $\mathrm{FeCaMgSO}_{4}$ ) are concerned, their size was lower than $99 \mu \mathrm{m}$ and most of them were lower than $10 \mu \mathrm{m}(60 \%)$. The size distribution results indicated that the sulfide concentrate was suitable for bioleaching [24].

Table 4. MLA results for main mineral constituents in sulfide concentrate (wt $\%$ ).

\begin{tabular}{cccc}
\hline Mineral & Content & Mineral & Content \\
\hline Pyrite & 40.0 & Quartz & 0.720 \\
\hline Pyrrhotite & 31.0 & Albite & 0.0600 \\
\hline Chalcopyrite & 1.77 & Hornblende & 0.360 \\
\hline Sphalerite & 1.31 & Pyroxene & 0.0300 \\
\hline Galena & 0.0100 & Muscovite & 0.0300 \\
\hline Magnetite, Hematite & 13.5 & Biotite & 0.610 \\
\hline Chromite & 0.0100 & Enstatite & 3.86 \\
\hline Ilmenite & 0.0100 & Calcite & 0.0400 \\
\hline Anhydrite & 0.0800 & Dolomite & 4.07 \\
\hline FeCaMgSO & 2.50 & - & - \\
\hline
\end{tabular}



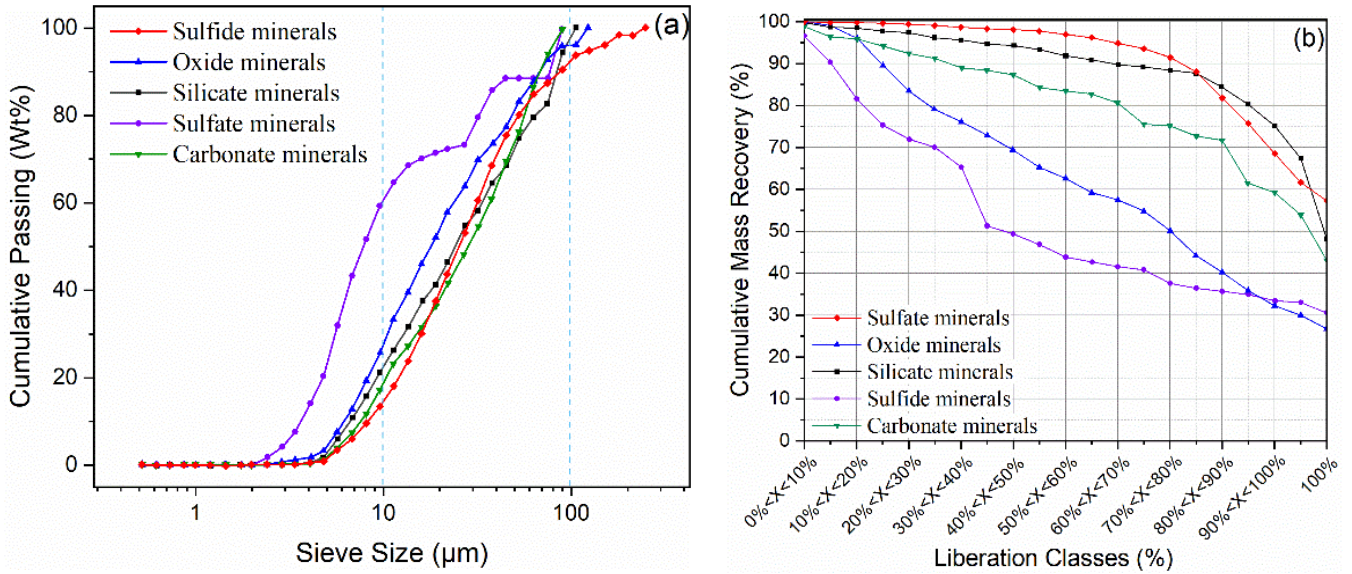

Figure 2. (a) Sieve size distribution for different minerals in sulfide concentrate; (b) liberation classes results for sulfide concentrate.

Analyzing the mineral liberation classes results in Figure $2 b$, the liberation characteristic of five categories was ordered: sulfide minerals $>$ silicate minerals $>$ carbonate minerals $>$ oxide minerals > sulfate minerals. Most importantly, the sulfide minerals present the best liberation characteristic and $57.3 \%$ of them had $100 \%$ liberation degree, which was higher than the rest of the other four type minerals. Because the $\mathrm{Cu}$ and $\mathrm{Zn}$ were mainly abundant in chalcopyrite and sphalerite, the suitable size and great liberation provide possibilities for recovery form sulfide concentrate by the artificial microbial community.

\subsection{Artificial Microbial Community Growth Characteristic Analysis}

It is widely known that microbial community composition mainly depended on environmental factors, such as $\mathrm{pH}$, temperature, and oxygen content. In order to better understand growth condition of the artificial microbial community, different $\mathrm{pH}$, temperature, and cultural revolving speed were determined, respectively. As shown in Figure 3a, the growth rate of microbial significant changed with $\mathrm{pH}$ ranging from 1.0 to 1.8. After 5 days, the artificial microbial community was in logarithmic phase. Moreover, better growth rates were observed with $\mathrm{pH}$ vales of 1.8 and 1.5, the average logarithmic cell concentration was $8.3 \times 10^{7}$ cell $/ \mathrm{mL}$ and $7.7 \times 10^{7}$ cell $/ \mathrm{mL}$ respectively. A lower growth rate was observed when $\mathrm{pH}$ value was 1.2 with average logarithmic cell concentration was $6.5 \times 10^{7}$ cell $/ \mathrm{mL}$. The lowest growth rate was observed at $\mathrm{pH}=1.0$ and the cell concentration was only $2.4 \times 10^{7}$ cell $/ \mathrm{mL}$. We could conclude that the most suitable $\mathrm{pH}$ value should be 1.8, which was similar to previous study (optimal $\mathrm{pH}$ value was 1.5) [35].


Figure 3. Culture condition results of (a) $\mathrm{pH}$, (b) temperature, and revolving speed for artificial microbial community. 
Furthermore, another two environmental factors of temperature and revolving speed were studied as well [28,29]. As shown in Figure 3b (Red Lines), the microorganism is significantly affected by culture temperature. The best growth rate presented under $30{ }^{\circ} \mathrm{C}$, and the number of microbials continued increasing within 1-10 days, which reached the maximum value about $6.1 \times 10^{7} \mathrm{cell} / \mathrm{mL}$. When the temperature was $45^{\circ} \mathrm{C}$, the growth rate was the fastest in the first three days, and the number of microorganisms attaining the maximum was about $4.7 \times 10^{7} \mathrm{cell} / \mathrm{mL}$ on the fifth day. However, the number of microorganisms decreased rapidly five days later, which reached to $2.2 \times 10^{7} \mathrm{cell} / \mathrm{mL}$. When the temperature was $55^{\circ} \mathrm{C}$, an unsatisfactory growth curve was performed and the cell concentration did not exceed $1.5 \times 10^{7} \mathrm{cell} / \mathrm{mL}$ in the whole culture process.

As far as rotation speed is concerned, the growth of microorganisms should be influenced notably. As shown in Figure 3b (Blue Lines), the fastest growth rate was observed with $160 \mathrm{r} / \mathrm{min}$ condition, and the number of microorganisms which reached the maximum value about $6.3 \times 10^{7} \mathrm{cell} / \mathrm{mL}$ on the fifth day. However, when the rotation speed was adjusted to $120 \mathrm{r} / \mathrm{min}$ or $190 \mathrm{r} / \mathrm{min}$, the average cell concentration was $2.8 \times 10^{7} \mathrm{cell} / \mathrm{mL}$ and $1.2 \times 10^{7}$ cell $/ \mathrm{mL}$ respectively. Based on the above results, we conclude that the artificial microbial community preferred values of $\mathrm{pH}$, temperature, and cultural revolving speed of $1.8,30^{\circ} \mathrm{C}$, and $160 \mathrm{r} / \mathrm{min}$ respectively.

\subsection{Reaction Condition Exploration for Leaching Process}

Based on the artificial microbial community growth characteristic analysis results, the leaching efficiency of $\mathrm{Cu}$ and $\mathrm{Zn}$ was studied under different $\mathrm{pH}(\mathrm{pH}=1.0,1.2,1.5,1.8)$ and different temperature $\left(35^{\circ} \mathrm{C}, 45^{\circ} \mathrm{C}, 55^{\circ} \mathrm{C}\right)$ conditions. As show in Figure 4 (left part), the highest leaching efficiency of $\mathrm{Cu}$ and $\mathrm{Zn}$ were observed when $\mathrm{pH}$ value was 1.2, and the value attained was $80 \%$ and $100 \%$ respectively. In addition, the leaching efficiency of $\mathrm{Cu}$ is similar when $\mathrm{pH}$ value was $1.0,1.5$, and 1.8 , only reached to $65 \%, 62 \%, 61 \%$, respectively. Meanwhile, the leaching efficiency of $\mathrm{Zn}$ is similar when $\mathrm{pH}$ value was 1.5 and 1.8, which reached to $95 \%$ and $94.5 \%$ respectively. However, the lowest leaching efficiency of Zn only came up to $85 \%$ when $\mathrm{pH}$ value was 1.0 . Therefore, the optimal $\mathrm{pH}$ value was 1.2 , which was different with the cell-culture value (1.8).

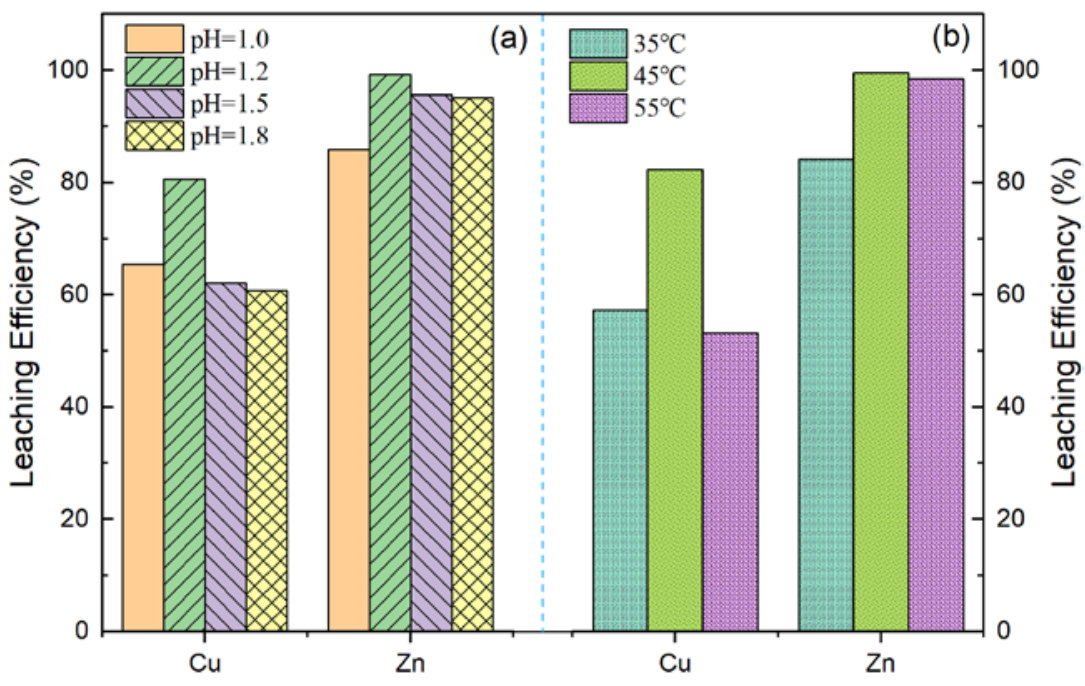

Figure 4. Leaching efficiency for $\mathrm{Cu}$ and $\mathrm{Zn}$ under (a) different $\mathrm{pH}$ and (b) different temperature conditions by the artificial microbial community.

Furthermore, the Figure 4 (right part) presented the highest leaching efficiency of $\mathrm{Cu}$ and $\mathrm{Zn}$ under $45^{\circ} \mathrm{C}$, which reached to $84 \%$ and $98 \%$ respectively. However, when temperature value reduced to $35^{\circ} \mathrm{C}$, the leaching efficiency of $\mathrm{Cu}$ was $58 \%$, and the value of $\mathrm{Zn}$ was $81 \%$. Meanwhile, when temperature raised to $55^{\circ} \mathrm{C}$, the leaching efficiency of $\mathrm{Cu}$ 
$\mathrm{Zn}$ reached to $51 \%$ and $97 \%$, respectively. Therefore, the preferred value of temperature was also changed from $35^{\circ} \mathrm{C}$ to $45^{\circ} \mathrm{C}$ in the experiments, compared with cell-culture process. We could conclude that the artificial microbial community has positive effect on the leaching efficiency of $\mathrm{Cu}$ and $\mathrm{Zn}$. However, the conditions of microbial growth and degradation need to be further corrected in practical engineering applications. Compared with the previous microorganism growth conditions, the preferred values of $\mathrm{pH}$ and temperature were changed in the experiments, the highest leaching efficiency of $\mathrm{Cu}$ and $\mathrm{Zn}$ which occurred in the value of $\mathrm{pH}$ and temperature was 1.2 and $45^{\circ} \mathrm{C}$ respectively, and the conditions have a slight difference with regard to previous related study [29].

In order to further improve the leaching efficiency of $\mathrm{Cu}$ and $\mathrm{Zn}$, the study of essential factors for ore pulp density and inoculation quantity was necessary [29]. The leaching efficiency of $\mathrm{Cu}$ and $\mathrm{Zn}$ in various of ore pulp density $(5 \%, 10 \%, 15 \%, 20 \%, 25 \%)$ were explored, while the $\mathrm{pH}$ value was 1.2 , temperature was $45^{\circ} \mathrm{C}$, and rotation speed was $160 \mathrm{r} / \mathrm{min}$. For the ore pulp density result presented in Figure 5 (red lines), the leaching efficiency of $\mathrm{Cu}$ and $\mathrm{Zn}$ increased at first and then decreased rapidly with the increasing of ore pulp density. The highest leaching efficiency of $\mathrm{Cu}$ and $\mathrm{Zn}$ reached to $100 \%$ and $79 \%$ on $20 \%$ ore pulp density. Meanwhile, when the ore pulp density was lower than $20 \%$, the leaching efficiency of $\mathrm{Cu}$ and $\mathrm{Zn}$ only attained to $74 \%$ and $84 \%$ respectively. Moreover, with $25 \%$ ore pulp density, the leaching efficiency of $\mathrm{Cu}$ and $\mathrm{Zn}$ decreased rapidly as well, which reached to $53 \%$ and $55 \%$ respectively.



Figure 5. Leaching efficiency curves determined by ore pulp density and inoculation quantity.

In addition, the inoculation quantity of microbial community is another essential factor for the leaching efficiency of $\mathrm{Cu}$ and $\mathrm{Zn}$. In this part, different inoculation quantity $(5 \%, 8 \%, 10 \%, 12 \%$, and $15 \%)$ were explored in the same conditions, with the value of ore pulp density is $20 \%$. Figure 5 (blue lines) shows the inoculation quantity results: with increasing inoculation quantity, the leaching efficiency of $\mathrm{Cu}$ and $\mathrm{Zn}$ increased at first and then decreased. The highest value occurred on $10 \%$ inoculation quantity, which reached to $82 \%$ and $100 \%$, present a non-linear relationship. At the same time, if the inoculation quantity (8\%) was smaller than 10\%, the leaching efficiency of $\mathrm{Cu}$ and $\mathrm{Zn}$ decreased to $77 \%$ 
and $85 \%$ respectively, and further reduced to $68 \%$ and $72 \%$ with the inoculation quantity of $5 \%$, when the inoculation quantity $(12 \%)$ was higher than $10 \%$, the leaching efficiency of $\mathrm{Cu}$ and $\mathrm{Zn}$ reduced to $78 \%$ and $87 \%$ respectively, and further reduced to $72 \%$ and $82 \%$ with the inoculation quantity of $15 \%$.

The trend of the leaching efficiency is inseparable with ore pulp density and inoculation quantity. We speculate that there are two reasons. Firstly, lower concentration of ore pulp density will not be enough to satisfy the adherent area of microorganisms, but higher concentration will hinder the exchange of microorganisms and ore pulp. As far as inoculation quantity is concerned, limited microorganisms result in lower leaching efficiency of $\mathrm{Cu}$ and $\mathrm{Zn}$, but the dissolved oxygen could not support superfluous microorganisms to maintain optimal activity. Based on the above results, we could conclude that ore pulp density and inoculation quantity were key factors affecting the leaching efficiency of $\mathrm{Cu}$ and $\mathrm{Zn}$ from sulfide concentrate. Therefore, $20 \%$ ore pulp density and the inoculation quantity of $10 \%$ are optimal conditions for engineering application in system.

\subsection{Efficient Performance for Novel Artificial Microbial Community}

Based on above experiment results, when the leaching efficiency of $\mathrm{Cu}$ and $\mathrm{Zn}$ have reached maximum, the optimal conditions were: $\mathrm{pH}$ was 1.2 , temperature was $45{ }^{\circ} \mathrm{C}$, artificial microbial community inoculation quantity was $10 \%$, and ore pulp density was $20 \%$. In order to explore the leaching efficiency performance by the novel artificial microbial community, control groups (leaching under aseptic conditions) without microbial were set up in the same time, which was used to compare with the experimental group.

As shown in Figure 6, the artificial microbial community had a significant effect on the leaching of $\mathrm{Cu}$ and $\mathrm{Zn}$. The points were as follows. For $\mathrm{Cu}$, the leaching rate of the control group increased steadily in the first eight days, and reached the maximum on the eighth day, with the average leaching rate of $45 \%$. Compared to control group, in the experimental group, the leaching rate increased steadily in the first ten days, and the growth rate was greater than the control group. The leaching rate of $\mathrm{Cu}$ reached the maximum on the tenth day, with an average leaching rate of $80 \%$. The increase of artificial microbial community lengthened the leaching cycle of $\mathrm{Cu}$, but the leaching rate of $\mathrm{Cu}$ was significantly increased, and the leaching rate of $\mathrm{Cu}$ in the experimental group was 1.8 times that of the control group. For $\mathrm{Zn}$, the leaching rate of control group and experimental group was higher than the $\mathrm{Cu}$. In the control group of $\mathrm{Zn}$, the leaching rate reached the maximum on the eighth day, with an average leaching rate of $80 \%$. However, after the addition of artificial microbial community, all $\mathrm{Zn}$ leaching on the sixth day and leaching rate was $100 \%$. The addition of artificial microbial community not only shortened the leaching cycle of $\mathrm{Zn}$, but also increased the leaching rate by 1.2 times. In a single microbial reaction system, the leaching rates of $\mathrm{Cu}$ and $\mathrm{Zn}$ by microorganisms were up to $62 \%$ and $77 \%$ [30]. Compared with the single microbial system, the novel artificial microorganism improves the leaching rate of $\mathrm{Cu}$ and $\mathrm{Zn}$ effectively, and the leaching efficiency is increased by $30 \%$ and $29 \%$.

All in all, comprehensive analysis shows that the artificial microbial community can significantly enhance the leaching rate of $\mathrm{Cu}$ and $\mathrm{Zn}$ from mine tailings, and the leaching rate of $\mathrm{Zn}$ was significantly higher than of $\mathrm{Cu}$. In addition, an artificial microbial community has the advantage of high efficiency and no pollution in leaching $\mathrm{Cu}$ and $\mathrm{Zn}$, which has important research significance in improving mineral recovery and degrading heavy metal pollution in the future. 




Figure 6. Copper and zinc recovery by the novel artificial microbial community.

\section{Conclusions}

As an environmentally friendly and high-efficiency bioleaching technologies scheme, the artificial microbial community's enhancement of the recovery of $\mathrm{Cu}$ and $\mathrm{Zn}$ was studied for the first time. The optimal experimental parameters ( $\mathrm{pH}$ value, temperature, and rotation speed) are unlike those between microorganism growth conditions and bioleaching experiments. Under the optimal conditions, the average recovery rate of $\mathrm{Cu}$ and $\mathrm{Zn}$ reached to $80 \%$ and $100 \%$ respectively, which almost increased $180 \%$ and $120 \%$ more than the control group. Further studies plan to optimize the novel artificial microbial community to leach more kinds of metal ions and provide different solutions for various kinds of low-grade ore.

Author Contributions: Conceptualization, X.C. (Xinglan Cui) and X.Y.; methodology, X.C. (Xiaokui Cui); software, H.L. and Q.Z. (Qidong Zhang); validation, J.Z., L.W. and X.H.; formal analysis, Q.Z. (Qi Zheng); investigation, R.J.; resources, Y.L.; data curation, X.C. (Xinglan Cui); writing-original draft preparation, X.C. (Xinglan Cui) and X.Y.; writing-review and editing, Y.L. All authors have read and agreed to the published version of the manuscript.

Funding: This research was funded by the National Key Research and Development Project (No. 2019YFC1805900), the National Key Research and Development Project (No. 2020YFC1807700), the Open Foundation of State Key Laboratory of Vanadium and Titanium Resources Comprehensive Utilization (No. 2021P4FZG13A), the Youth Fund Project of GRINM (No. 12008, No12119 and No12120), National Natural Science Foundation of China (No. 51704028), and the Open Foundation of State Key Laboratory of Mineral Processing (No. BGRIMM-KJSKL-2020-07).

Institutional Review Board Statement: Not applicable.

Informed Consent Statement: Not applicable.

Data Availability Statement: The data presented in this study are available on request from the corresponding author.

Conflicts of Interest: The authors declare no conflict of interest. 


\section{References}

1. Chen, J.; Jiskani, I.M.; Jinliang, C.; Yan, H. Evaluation and future framework of green mine construction in China based on the DPSIR model. Sustain. Environ. Res. 2020, 30, 448-457. [CrossRef]

2. Wei, X.; Liu, H.; Li, G. Influencing Factors of Eco-Environmental Safety of Mines and Their Green Development: A Case Study of Taoshan Coal Mine in Heilongjiang Province, China. Nat. Environ. Polution Technol. 2020, 19, 831-838.

3. Martinez, P.; Vera, M.; Bobadilla-Fazzini, R. Omics on bioleaching: Current and future impacts. Appl. Microbiol. Biotechnol. 2015, 99, 8337-8350. [CrossRef]

4. Bobadilla-Fazzini, R.A.; Pérez, A.; Gautier, V.; Jordan, H.; Parada, P. Primary copper sulfides bioleaching vs. chloride leaching: Advantages and drawbacks. Hydrometallurgy 2017, 168, 26-31. [CrossRef]

5. Hernandez, S. The World of Copper Factbook; International Copper Study Group: Lisbon, Portugal, 2017 ; pp. 1-58.

6. Hallberg, K.B.; Gonza 'lez-Toril, E.; Johnson, D.B. Acidithiobacillus ferrivorans, sp. nov.; facultatively anaerobic, psychrotolerant iron-, and sulfur-oxidizing acidophiles isolated from metal mine-impacted environments. Extremophiles 2010, 14, 9-19. [CrossRef]

7. Ilyas, S.; Chi, R.-A.; Lee, J.-C. Fungal Bioleaching of Metals from Mine Tailing. Miner. Process. Extr. Met. Rev. 2013, 34, 185-194. [CrossRef]

8. Panda, S.; Akcil, A.; Pradhan, N.; Deveci, H. Current scenario of chalcopyrite bioleaching: A review on the recent advances to its heap-leach technology. Bioresour. Technol. 2015, 196, 694-706. [CrossRef]

9. Feng, S.; Yang, H.; Wang, W. Insights to the effects of free cells on community structure of attached cells and chalcopyrite bioleaching during different stages. Bioresour. Technol. 2016, 200, 186-193. [CrossRef]

10. Africa, C.; Van Hille, R. Investigation and in situ visualisation of interfacial interactions of thermophilic microorganisms with metal-sulfides in a simulated heap environment. Miner. Eng. 2013, 48, 100-107. [CrossRef]

11. Wang, X.; Ma, L.; Wu, J.; Xiao, Y.; Tao, J.; Liu, X. Effective bioleaching of low-grade copper ores: Insights from microbial cross experiments. Bioresour. Technol. 2020, 308, 123273. [CrossRef]

12. Ke, Z.; Zhao, X.; Feng, Y.; Wang, Q.; Wang, Y.; Zhang, C.; Zhu, B.; Ren, G. Semiconducting Minerals Participated Extracellular Electron Transfer Process in High-Altitude Red Soil from Gansu, China. Geomicrobiol. J. 2021, 38, 905-913. [CrossRef]

13. Zeng, J.; Gou, M.; Tang, Y.-Q.; Li, G.-Y.; Sun, Z.-Y.; Kida, K. Effective bioleaching of chromium in tannery sludge with an enriched sulfur-oxidizing bacterial community. Bioresour. Technol. 2016, 218, 859-866. [CrossRef] [PubMed]

14. Zheng, C.; Huang, Y.; Guo, J.; Cai, R.; Zheng, H.; Lin, C.; Chen, Q. Investigation of cleaner sulfide mineral oxidation technology: Simulation and evaluation of stirred bioreactors for gold-bioleaching process. J. Clean. Prod. 2018, 192, 364-375. [CrossRef]

15. Holmes, D. Review of International Biohydrometallurgy Symposium, Frankfurt, 2007. Hydrometallurgy 2008, 92, 69-72. [CrossRef]

16. Chen, S.-Y.; Pan, S.-H. Simultaneous metal leaching and sludge digestion by thermophilic microorganisms: Effect of solids content. J. Hazard. Mater. 2010, 179, 340-347. [CrossRef]

17. Chen, S.-Y.; Lin, J.-G. Bioleaching of heavy metals from contaminated sediment by indigenous sulfur-oxidizing bacteria in an air-lift bioreactor: Effects of sulfur concentration. Water Res. 2004, 38, 3205-3214. [CrossRef]

18. Deng, X.; Chai, L.; Yang, Z. Bioleaching of heavy metals from a contaminated soil using indigenous Penicillium chrysogenum strain F1. J. Hazard. Mater. 2012, 233-234, 25-32. [CrossRef]

19. Blais, J.; Tyagi, R.; Auclair, J. Bioleaching of metals from sewage sludge: Microorganisms and growth kinetics. Water Res. 1993, 27, 101-110. [CrossRef]

20. Hopfe, S.; Flemming, K.; Lehmann, F.; Möckel, R.; Kutschke, S.; Pollmann, K. Leaching of rare earth elements from fluorescent powder using the tea fungus Kombucha. Waste Manag. 2017, 62, 211-221. [CrossRef]

21. Kaksonen, A.; Boxall, N.; Gumulya, Y. Recent progress in biohydrometallurgy and microbial characterization. Hydrometallurgy 2018, 180, 7-25. [CrossRef]

22. Pathak, A.; Morrison, L.; Healy, M.G. Catalytic potential of selected metal ions for bioleaching, and potential techno-economic and environmental issues: A critical review. Bioresour. Technol. 2017, 229, 211-221. [CrossRef]

23. Asghari, I.; Mousavi, S.M.; Amiri, F.; Tavassoli, S. Bioleaching of spent refinery catalysts: A review. J. Ind. Eng. Chem. 2013, 19, 1069-1081. [CrossRef]

24. Shang, H.; Gao, W.-C.; Wu, B.; Wen, J.-K. Bioleaching and dissolution kinetics of pyrite, chalcocite and covellite. J. Cent. South Univ. 2021, 28, 2037-2051. [CrossRef]

25. Tuovinen, O.; Särkijärvi, S.; Peuraniemi, E. Acid Leaching of $\mathrm{Cu}$ and $\mathrm{Zn}$ from a Smelter Slag with a Bacterial Consortium. Adv. Mater. Res. 2015, 1130, 660-663. [CrossRef]

26. Nguyen, V.K.; Lee, J.U. A comparison of microbial leaching and chemical leaching of arsenic and heavy metals from mine tailings. Biotechnol. Bioprocess Eng. 2015, 20, 91-99. [CrossRef]

27. Cui, X.; Wang, X. Bioleaching of a complex Co-Ni-Cu sulfide flotation concentrate by Bacillus megaterium QM B1551 at neutral pH. Geomicrobiol. J. 2016, 3, 734-741. [CrossRef]

28. Seh-Bardan, B.J.; Othman, R.; Ab Wahid, S.; Husin, A.; Sadegh-Zadeh, F. Bioleaching of Heavy Metals from Mine Tailings by Aspergillus fumigatus. Bioremediat. J. 2012, 16, 57-65. [CrossRef]

29. Cui, J.; Zhu, N.; Mao, F.; Wu, P.; Dang, Z. Bioleaching of indium from waste LCD panels by Aspergillus niger: Method optimization and mechanism analysis. Sci. Total. Environ. 2021, 790, 148151. [CrossRef]

30. Couillard, D.; Mercier, G. Bacterial leaching of heavy metals from sewage sludge-bioreactors comparison. Environ. Pollut. 1990, 66, 237-252. [CrossRef] 
31. Liang, Y.L.; Yin, H.Q.; Xiao, Y.H.; Tang, M.; Feng, X.; Xie, Z.Y.; Qiu, G.Z.; Liu, X.D. Microbial Leaching of Copper from Tailings of Low Grade Sulphide Ores in Zambia. Adv. Mater. Res. 2015, 1130, 473-476. [CrossRef]

32. Srichandan, H.; Mohapatra, R.K.; Parhi, P.K.; Mishra, S. Bioleaching approach for extraction of metal values from secondary solid wastes: A critical review. Hydrometallurgy 2019, 189, 105122. [CrossRef]

33. Li, J.; Meng, X.; Zhao, H.; Zhang, Y.; Liu, R.; Gu, G. Efficient separation of zinc from zinc containing copper sulfide concentrate by chemical leaching. Chem. Erde-Geochem. 2021, 107, 125773. [CrossRef]

34. Arshadi, M.; Pourhossein, F.; Mousavi, S.M.; Yaghmaei, S. Green recovery of Cu-Ni-Fe from a mixture of spent PCBs using adapted A. ferrooxidans in a bubble column bioreactor. Sep. Purif. Technol. 2021, 272, 118701. [CrossRef]

35. Mäkinen, J.; Heikola, T.; Salo, M.; Kinnunen, P. The Effects of Milling and pH on Co, Ni, Zn and Cu Bioleaching from Polymetallic Sulfide Concentrate. Minerals 2021, 11, 317. [CrossRef] 